\title{
Chemical characterization of vermicompost of sewage sludge with different proportions of diatomaceous material
}

\author{
Fabíola M. Braga ${ }^{1}$, Paulo H. S. Cardoso ${ }^{1}$, Mário H. C. Barbosa ${ }^{1}$, \\ Márcio N. Rodrigues ${ }^{1}$, Regynaldo A. Sampaio ${ }^{1} \&$ Luiz A. Fernandes ${ }^{1}$ \\ ${ }^{1}$ Universidade Federal de Minas Gerais/Instituto de Ciências Agrárias. Montes Claros, MG. E-mail: fabiolambraga@gmail.com (Corresponding author); \\ paulohenrique.sc@hotmail.com; marioh.ufmg@gmail.com; marcionrodrigues@gmail.com; rsampaio@ufmg.br; larnaldo@ufmg.br
}

Key words:

biosolid

Eisenia foetida

organic compost

\begin{abstract}
A B S T R A C T
The pursuit for waste recovery has been the best way to contribute to environmental sustainability. The mix of sewage sludge (SS) from Sewage Treatment Plant with diatomaceous material containing oil (DE), used as a filter in biofuel production, can form a substrate rich in minerals and organic matter through vermicomposting. Therefore, this study aimed to produce vermicompost using worms, Eisenia foetida, from a pre-compost (PC) of sewage sludge and garden pruning residues mixed with different proportions of DE in relation to PC: $0 ; 7.53 ; 15.06 ; 22.59$; and $30.12 \% \mathrm{v} / \mathrm{v}$. The design was randomized complete blocks with five treatment replicates. The chemical characteristics of the vermicompost were analyzed after a period of four months. The proportion of up to $30.12 \% \mathrm{v} / \mathrm{v}$ of DE met the criteria established for agriculture uses, registration and marketing of the product as organic compost in accordance with the Normative Instructions SDA 27/2006 and 25/2009 from the Ministry of Agriculture.
\end{abstract}

\section{Palavras-chave:}

biossólido

Eisenia foetida

composto orgânico

\section{Caracterização química de vermicomposto de lodo de esgoto com diferentes proporções de terra de diatomácea}

\begin{abstract}
R E S U M O
A busca por aproveitamento de resíduos tem sido a melhor maneira de contribuir para a sustentabilidade ambiental. Com a mistura do lodo (LE) de Estações de Tratamento de Esgotos e a terra de diatomácea contendo óleo (TD), utilizada como filtro na produção de biocombustível, é possível formar um substrato rico em minerais e matéria orgânica por meio da vermicompostagem. Desta maneira objetivou-se produzir um vermicomposto utilizando-se minhocas Eisenia foetida, a partir de um pré-composto (PC) de lodo de esgoto e podas de jardinagem, misturado com diferentes proporções de TD proveniente de processo de fabricação de óleo biocombustível. Os tratamentos corresponderam às seguintes proporções de TD em relação ao PC: 0; 7,53; 15,06; 22,59 e 30,12\% v/v. O delineamento utilizado foi em blocos casualizados, com cinco repetições dos tratamentos. Transcorridos quatro meses foram analisadas as características químicas do vermicomposto. A proporção de até $30,12 \% \mathrm{v} / \mathrm{v}$ de TD atendeu aos critérios estabelecidos para uso agrícola, registro e comercialização do produto como composto orgânico, conforme estabelecido nas Instruções Normativas 27/2006 e 25/2009 do Ministério da Agricultura.
\end{abstract}




\section{INTRODUCTION}

The sludge originated from urban sewage treatment is a waste with high organic content and with inorganic components, presenting a challenge for the Sewage Treatment Plants (STPs) with respect to its disposal, due to the large volume generated, caused by the population growth (Caldeira et al., 2013).

Despite being widely used in agriculture because of its chemical properties, the sludge has some limiting factors, such as pathogenicity, high content of heavy metals and toxic organic compounds, characteristic odor, among others (Paredes Filho, 2011).

There are various alternatives of sewage sludge (SS) stabilization, in order to reduce the presence of pathogens and allow its agricultural utilization. One of them is vermicomposting, which can reduce the quantities of viable eggs of helminths through the digestive tract of the earthworms, causing the final product to have excellent agronomic potential (Dores-Silva et al., 2011a). However, not always the single sanitization of the sludge is sufficient for it to be used in agriculture. The CONAMA resolution 375 defines criteria and procedures for the agricultural use of sewage sludge and its derivatives, establishing maximum limits and some measures that must be taken for its correct utilization (BRASIL, 2006b).

Diatomaceous earth $(\mathrm{DE})$ is a material with sedimentary origin, basically constituted of skeletons or frustules, being friable, porous and fine. It is mainly composed of silica, but may have traces of aluminum, iron and some metals. For showing these characteristics, it may help in the improvement of the physical conditions of a substrate, besides having the capacity to absorb its own weight in water (Goulart et al., 2011). In addition, it has been used as filter in the filtering of biofuel in plants, forming a residue of diatomaceous earth soaked in oil.

The objective of mixing sewage sludge with diatomaceous earth is to produce a substrate that is adequate to be used in plant cultivation and, at the same time, promote environmental sustainability. Given the above, this study aimed to verify the possibility of vermicomposting DE soaked in biofuel oil and evaluate the ideal proportion of DE in the vermicomposting of sewage sludge and plant residues, for production, registration and marketing of organic compost.

\section{Material ANd Methods}

The study was carried at the Institute of Agricultural Sciences of the Federal University of Minas Gerais (ICA/ UFMG) on the campus of Montes Claros, MG, in protected environment (covered shed with sides closed by shade cloth). Pre-composting was performed from September to November 2014 , in a total of seven weeks, using, in volume, three parts of plant residues from the campus garden pruning for one part of solarized sewage sludge obtained in the STP of Montes Claros, MG. The material was turned once a week along the period of pre-composting.

Vermicomposting was performed from November 2014 to April 2015, in a total of four months, using a randomized complete block statistical design with five treatments and five replicates. The treatments consisted in the mixture of DE residue with pre-compost (PC) produced at the following proportions (\%, v/v): T1 - 0:100; T2 - 7.53:92.47; T3 15.06:84.94; T4 - 22.59:77.41; T5 - 30.12:69.88, respectively. The mixture had final volume of $80 \mathrm{~L}$ and was made in plastic containers with capacity for $100 \mathrm{~L}$, arranged on a slight slope to drain the possible excess of water, which could then be collected and returned to the container.

Each experimental unit received $1 \mathrm{~kg}$ of redworms (Eisenia foetida). The containers were covered with shade cloth to avoid excessive evaporation or drying of the substrate, protect the earthworms from predators and prevent their escape. Substrate moisture was daily measured by hand pressing the samples and observing if the water drained or if the sample was dry (without moistening the palm of the hand). Water was replenished to maintain the moisture close to the substrate water holding capacity, by returning the drained excess of water to the container. The mixture was monthly turned by hand, to avoid damages to the earthworms and compaction, facilitating aeration and drainage.

The different DE proportions caused initial stress on the earthworms, especially in the treatments with greater proportion of this residue. This fact can occur because this material is soaked in oil, which compromises the cutaneous respiration of the earthworms. To attenuate this effect and facilitate the adaptation of the earthworms, a 1-cm layer of PC was placed on the evaluated substrate. However, the added layer was taken into account in the calculation of the relationship of the volumes described for the treatments, which caused the values to be fractioned. As soon as the PC was added, there was rapid adaptation of the earthworms, with no deleterious effects.

After four months, samples of the substrate produced in each experimental unit were taken to the Laboratories of Analyses of Residues for Agricultural Use (LARAA) and of Agrochemistry Research (LPA) of the ICA/UFMG, to determine the contents of $\mathrm{N}$ and $\mathrm{Al}^{3+}$ (Tedesco et al., 1995), $\mathrm{pH}$, cation exchange capacity (CEC), contents of $\mathrm{K}, \mathrm{P}, \mathrm{S}, \mathrm{Na}$, organic carbon (Alcarde, 2009), As, Pb, Cr, Co, Ni, Fe, Ca, Mg, $\mathrm{Mo}, \mathrm{Cu}, \mathrm{Zn}, \mathrm{Ba}, \mathrm{Cd}, \mathrm{Mn}, \mathrm{Al}$ and Se (EPA, 1994). Table 1 shows the physical-chemical characteristics of the sewage sludge, precompost and diatomaceous earth used in the study.

The obtained results were subjected to analysis of variance and regression equations were fitted, testing the significance of the coefficients up to 0.10 probability level by t-test using the $\mathrm{R}$ software version 3.2.0.

\section{Results AND Discussion}

The total contents of $\mathrm{N}, \mathrm{P}, \mathrm{Ca}$ and $\mathrm{K}$ were reduced in the vermicomposting of sewage sludge and plant residues with the increase in the volumetric proportion of diatomaceous earth (Table 2). This fact can be justified by the low contents of these nutrients in the DE (Table 1), causing these nutrients to be diluted in the vermicompost as the residue is added. However, the reached levels, even at the greatest proportion of DE, still meet the limits established by the legislations IN 27/2006 (BRASIL, 2006a), IN 25/2009 (BRASIL, 2009) and CONAMA 375 (BRASIL, 2006b). 
Table 1. Chemical characterization of the sewage sludge (SS), pre-compost (PC) and diatomaceous earth (DE)

\begin{tabular}{|c|c|c|c|}
\hline Parameters & SS & PC & $\overline{D E}$ \\
\hline $\operatorname{Org} C\left(\mathrm{~g} \mathrm{~kg}^{-1}\right)$ & 286.20 & 250.20 & 482.40 \\
\hline$N\left(g_{k g}^{-1}\right)$ & 22.02 & 18.83 & 0.67 \\
\hline$P\left(g_{k g}^{-1}\right)$ & 15.28 & 15.28 & 0.64 \\
\hline $\mathrm{K}\left(\mathrm{g} \mathrm{kg}^{-1}\right)$ & 2.31 & 2.49 & nd \\
\hline$S\left(\mathrm{~g} \mathrm{~kg}^{-1}\right)$ & 62.70 & 61.39 & 64.32 \\
\hline $\mathrm{Ca}\left(\mathrm{g} \mathrm{kg}^{-1}\right)$ & 2.67 & 2.53 & 1.15 \\
\hline $\mathrm{Mg}\left(\mathrm{g} \mathrm{kg}^{-1}\right)$ & 2.68 & 2.64 & 2.32 \\
\hline $\operatorname{Mn}\left(\mathrm{mg} \mathrm{kg}^{-1}\right)$ & 94.20 & 119.25 & 4.40 \\
\hline $\mathrm{Ni}\left(\mathrm{mg} \mathrm{kg}^{-1}\right)$ & 25.50 & 25.25 & 9.70 \\
\hline $\mathrm{Fe}\left(\mathrm{mg} \mathrm{kg}^{-1}\right)$ & $28,000.00$ & $50,895.00$ & 165.30 \\
\hline $\mathrm{Zn}\left(\mathrm{mg} \mathrm{kg}^{-1}\right)$ & 726.25 & 613.75 & 9.85 \\
\hline $\mathrm{Cu}\left(\mathrm{mg} \mathrm{kg}^{-1}\right)$ & 195.55 & 177.45 & 6.70 \\
\hline $\mathrm{Na}\left(\mathrm{mg} \mathrm{kg}^{-1}\right)$ & 122.36 & 132.05 & 199.84 \\
\hline $\mathrm{Al}\left(\mathrm{mg} \mathrm{kg}^{-1}\right)$ & $6,403.50$ & $6,210.00$ & 769.20 \\
\hline $\mathrm{Al}^{3+}\left(\mathrm{mg} \mathrm{kg}^{-1}\right)$ & 33.54 & 36.02 & 126.56 \\
\hline Se $\left(\mathrm{mg} \mathrm{kg}^{-1}\right)$ & 0.31 & 0.23 & $\mathrm{nq}$ \\
\hline As $\left(\mathrm{mg} \mathrm{kg}^{-1}\right)$ & 0.28 & 0.25 & 0.28 \\
\hline CEC $\left(\mathrm{mmol}_{\mathrm{c}} \mathrm{kg}^{-1}\right)$ & 540.00 & 492.50 & 387.50 \\
\hline C/N ratio & 13.00 & 13.29 & 720.00 \\
\hline $\mathrm{CEC} / \mathrm{C}$ ratio & 18.87 & 19.68 & 8.03 \\
\hline $\mathrm{pH}\left(\mathrm{CaCl}_{2}\right)$ & 6.10 & 6.10 & 4.30 \\
\hline
\end{tabular}

$\mathrm{Ba}, \mathrm{Cd}, \mathrm{Pb}, \mathrm{Co}$ and $\mathrm{Cr}$ were not quantified and Mo was not detected; CEC - Cation exchange capacity; Org C - Organic carbon; nq - Not quantified; nd - Not detected

According to the Normative Instruction 25/2009 (BRASIL, 2009), published by the Ministry of Agriculture and Livestock (MAPA), which established norms on the specifications, guarantees, tolerances, registration, packaging and labeling of organic and organomineral fertilizers and biofertilizers used in agriculture, the minimum $\mathrm{N}$ content for the marketing of an organic fertilizer is $5.0 \mathrm{~g} \mathrm{~kg}^{-1}$. Thus, at the proportion of $30.12 \%$ of DE added to the PC, the vermicompost can be commercialized, since it reached $\mathrm{N}$ content of $11.77 \mathrm{~g} \mathrm{~kg}^{-1}$ (Table 2). On the other hand, the vermicompost without DE addition showed $\mathrm{N}$ content of $18.37 \mathrm{~g} \mathrm{~kg}^{-1}$. However, it should be highlighted that, in vermicomposting with only SS, DoresSilva et al. (2011a) obtained $\mathrm{N}$ content of $33.7 \mathrm{~g} \mathrm{~kg}^{-1}$, whereas
Nascimento et al. (2013), in vermicomposting of SS and plant residues, obtained content of $13.9 \mathrm{~g} \mathrm{~kg}^{-1}$.

The previously mentioned norms do not establish minimum values for the other nutrients; however, the reductions in their contents with the increment of DE were $4.18 \mathrm{~g} \mathrm{~kg}^{-1}$ for $\mathrm{P}, 0.84$ $\mathrm{g} \mathrm{kg}^{-1}$ for $\mathrm{K}$ and $1.44 \mathrm{~g} \mathrm{~kg}^{-1}$ for Ca.

The $\mathrm{P}$ content of $11.43 \mathrm{mg} \mathrm{kg}^{-1}$ in the vermicompost with highest DE proportion was considered as similar to that obtained by Dores-Silva et al. (2011a) in vermicompost with pure SS, which was equal to $11.8 \mathrm{~g} \mathrm{~kg}^{-1}$, and much higher than that obtained by Nascimento et al. (2013) in vermicompost of $\mathrm{SS}$ and plant residues, $3.0 \mathrm{~g} \mathrm{~kg}^{-1}$. For $\mathrm{K}$ and $\mathrm{Ca}$, the values found by these authors were 4.0 and $4.9 \mathrm{~g} \mathrm{~kg}^{-1}$, respectively, higher than those observed in the present study.

$\mathrm{K}$ was the macronutrient with lowest content in the SS and in the PC (Table 1), which led to lower content of this element in the final vermicompost. However, there is a possibility of enriching the vermicompost with $\mathrm{K}$ through the addition of mineral fertilizer, because of its importance in plant development. Barbosa et al. (2007) reported reductions in $\mathrm{K}$ contents, after 100 days of incubation, mixing SS and soil. The low K contents usually observed in SS are attributed to the high solubility of this element, which causes most of it to remain in the wastewaters disposed in the water courses by the STPs.

The mean content of total organic C (267.12 $\left.\mathrm{g} \mathrm{kg}^{-1}\right)$ was considered as close to that described by Dores-Silva et al. (2011a), who observed content of $210.0 \mathrm{~g} \mathrm{~kg}^{-1}$ in SS vermicompost, and much higher than the minimum of 100.0 $\mathrm{g} \mathrm{kg}^{-1}$ required by the IN 25/2009 (BRASIL, 2009). The stability of the organic $\mathrm{C}$ contents with the increment of DE (Table 2) can be explained by the fact that most of this element in the residue comes from vegetal oil, which is decomposed by the microorganisms. Dores-Silva et al. (2011a, 2011b) highlight that, in the vermicomposting process, part of the organic $\mathrm{C}$ starts to participate in the earthworm biomass and another

Table 2. Adjusted regression equations for the chemical attributes analyzed in the vermicompost after addition of different proportions of diatomaceous earth

\begin{tabular}{|c|c|c|c|c|c|}
\hline Attribute & Fitted regression equations & $\mathbf{R}^{2}$ & CV (\%) & CVH & MCA \\
\hline $\operatorname{Org} C\left(\mathrm{~g} \mathrm{~kg}^{-1}\right)$ & $\hat{y}=\bar{y}=267.12 \pm 28.41^{a}$ & --- & 25.15 & 267.12 & $100.0^{3}$ \\
\hline$N\left(\mathrm{~g} \mathrm{~kg}^{-1}\right)$ & $\hat{y}=18.37-0.2192^{\star * *} x$ & 0.98 & 5.26 & 11.77 & $5.0^{3}$ \\
\hline$P\left(g_{k g}^{-1}\right)$ & $\hat{y}=15.61-0.1388^{* \star *} x$ & 0.95 & 7.47 & 11.43 & --- \\
\hline $\mathrm{K}\left(\mathrm{g} \mathrm{kg}^{-1}\right)$ & $\hat{y}=3.04-0.0279^{\star \star \star} x$ & 0.83 & 11.49 & 2.20 & --- \\
\hline$S\left(g_{k g}^{-1}\right)$ & $\hat{y}=\bar{y}=62.47 \pm 3.51^{a}$ & --- & 14.17 & 62.47 & --- \\
\hline $\mathrm{Ca}\left(\mathrm{g} \mathrm{kg}^{-1}\right)$ & $\hat{y}=4.43-0.0482^{* * *} x$ & 0.98 & 10.58 & 2.99 & --- \\
\hline $\operatorname{Mg}\left(\mathrm{g} \mathrm{kg}^{-1}\right)$ & $\hat{y}=\bar{y}=2.33 \pm 0.11^{a}$ & --- & 12.25 & 2.33 & --- \\
\hline $\mathrm{Na}\left(\mathrm{mg} \mathrm{kg}^{-1}\right)$ & $\hat{y}=162.37+22.9404^{\star \star *} x$ & 0.99 & 7.59 & 853.34 & --- \\
\hline $\mathrm{Fe}\left(\mathrm{mg} \mathrm{kg}^{-1}\right)$ & $\hat{y}=25,455.20-346.7596^{\star * *} x$ & 0.99 & 3.89 & $15,010.80$ & --- \\
\hline $\mathrm{Zn}\left(\mathrm{mg} \mathrm{kg}^{-1}\right)$ & $\hat{y}=636.20-10.4715^{\star * \star} x$ & 0.99 & 4.76 & 320.80 & $2800.0^{1}$ \\
\hline $\mathrm{Cu}\left(\mathrm{mg} \mathrm{kg}^{-1}\right)$ & $\hat{y}=187.60-1.7620^{\star} x-0.0173^{\star \star} x^{2}+0.0043^{* \star} x^{3}$ & 0.99 & 3.15 & 94.40 & $1500.0^{1}$ \\
\hline $\operatorname{Mn}\left(\mathrm{mg} \mathrm{kg}^{-1}\right)$ & $\hat{y}=154.19+3.8556^{* \star *} x-0.4966^{n s} x^{2}+0.0099^{*} x^{3}$ & 0.99 & 10.39 & 91.40 & --- \\
\hline $\mathrm{Al}\left(\mathrm{mg} \mathrm{kg}^{-1}\right)$ & $\hat{y}=7,738.61-113.7195^{\star \star \star} x$ & 0.99 & 6.70 & $4,313.40$ & --- \\
\hline $\mathrm{Al}^{3+}\left(\mathrm{mg} \mathrm{kg}^{-1}\right)$ & $\hat{y}=33.22+1.2006^{n s} x-0.0470^{\circ} x^{2}$ & 0.83 & 35.12 & 26.74 & --- \\
\hline Se $\left(\mathrm{mg} \mathrm{kg}^{-1}\right)$ & $\hat{y}=0.28-0.0146^{*} x+0.0013^{*} x^{2}-0.00003^{*} x^{3}$ & 0.84 & 18.56 & 0.20 & $100.0^{1} ; 80.0^{2}$ \\
\hline As $\left(\mathrm{mg} \mathrm{kg}^{-1}\right)$ & $\hat{y}=\bar{y}=0.22 \pm 0.11^{a}$ & --- & 117.71 & 0.22 & $41.0^{1} ; 20.0^{2}$ \\
\hline $\mathrm{CEC}\left(\mathrm{mmol}_{\mathrm{c}} \mathrm{kg}^{-1}\right)$ & $\hat{y}=547.10-5.4582^{\star *} x^{2}$ & 0.95 & 11.55 & 382.70 & --- \\
\hline $\mathrm{CEC} / \mathrm{C}$ ratio & $\hat{y}=\bar{y}=18.01 \pm 1.38^{a}$ & --- & 19.78 & 18.01 & --- \\
\hline $\mathrm{C} / \mathrm{N}$ ratio & $\hat{y}=\bar{y}=17.93 \pm 1.77^{a}$ & --- & 25.77 & 17.93 & $14.0^{3}$ \\
\hline $\mathrm{pH}$ (in $\mathrm{CaCl}_{2}$ ) & $\hat{y}=5.99-0.0357^{n s} x+0.0015^{\star} x^{2}$ & 0.91 & 4.47 & 6.23 & $6.0^{3}$ \\
\hline
\end{tabular}

$\mathrm{CVH}$ - Content of the attribute in the vermicompost with highest DE dose; MCA - Maximum content allowed by ${ }^{1}$ CONAMA 375 and ${ }^{2}$ IN $27 / 2006$ and minimum by ${ }^{3}$ IN 25/2009; ns - Not significant up to 0.10 probability level by t-test; ${ }^{\circ},{ }^{*},{ }^{\star *},{ }^{\star \star *}$ Significant at $0.10,0.05,0.01,0.001$ probability levels by t-test, respectively; a Means followed by the confidence interval at 0.10 probability level by t-test 
part is transformed into $\mathrm{CO}_{2}$. Lopes et al. (2008) indicate a value of organic $\mathrm{C}$ above $25 \%$ as ideal for substrates, and the generated vermicompost is slightly above the proportion considered as adequate.

For the nutrients $\mathrm{Mg}$ and $\mathrm{S}$, the contents did not change with the increment of $\mathrm{DE}$, despite the low $\mathrm{Mg}$ content in the DE (Table 1). The mean values obtained for these elements were 2.33 and $62.47 \mathrm{~g} \mathrm{~kg}^{-1}$, respectively, which were higher than those reported by Nascimento et al. (2013), 1.5 and $9.2 \mathrm{~g}$ $\mathrm{kg}^{-1}$, respectively. However, the few reductions observed in the contents of some nutrients with the addition of up to $30.12 \%$ of DE can be compensated by the permanent physical benefits promoted by the addition of this residue in the PC.

The contents of the elements $\mathrm{Fe}, \mathrm{Zn}, \mathrm{Cu}, \mathrm{Mn}, \mathrm{Al}$ and Se decreased with the DE addition to the vermicomposting process (Table 2), since this residue has low contents of these elements in its composition (Table 1 ). Thus, with the addition of up to $30.12 \%$ of DE, the reductions were $10,444.40 \mathrm{mg} \mathrm{kg}^{-1}$ for $\mathrm{Fe}, 315.40 \mathrm{mg} \mathrm{kg}^{-1}$ for $\mathrm{Zn}, 93.20 \mathrm{mg} \mathrm{kg}^{-1}$ for $\mathrm{Cu}$ and $62.80 \mathrm{mg}$ $\mathrm{kg}^{-1}$ for Mn. Therefore, there was an evident impoverishment of the substrate in micronutrients for the plants, as already observed for macronutrients. Despite that, the achieved values of $\mathrm{Zn}$ and $\mathrm{Cu}$ are close to those obtained by Nascimento et al. (2014) in vermicompost of SS and plant residues, which were equal to 374 and $71 \mathrm{mg} \mathrm{kg}^{-1}$, respectively. For Fe and $\mathrm{Mn}$, Hashemimajd \& Jamaati-e-Somarin (2011) reported contents ranging from 3,000 to $6,000 \mathrm{mg} \mathrm{kg}^{-1}$ and from 225 to $300 \mathrm{mg}$ $\mathrm{kg}^{-1}$, respectively, in vermicompost of SS and plant residues.

With the addition of $30.12 \%$ of DE, the total $\mathrm{Al}$ content decreased by $3,425.20 \mathrm{mg} \mathrm{kg}^{-1}$ and exchangeable Al decreased by $6.48 \mathrm{mg} \mathrm{kg}^{-1}$ (Table 2). Corrêa et al. (2007) point out that the high $\mathrm{Al}$ content in the sludge, when the sewage treatment in the station involves the addition of $\mathrm{AlCl}_{3}$, can reach values on the order of $3,700 \mathrm{mg} \mathrm{kg}^{-1}$, but the content becomes much higher after the process of organic matter mineralization. In spite of that, with $\mathrm{pH}$ values of the vermicompost usually close to neutrality, $\mathrm{Al}$ precipitates and is complexed by the humus, thus becoming unavailable to the plants, although only $0.15 \%$ of this element is found in the exchangeable form. The exchangeable $\mathrm{Al}$ content of $26.74 \mathrm{mg} \mathrm{kg}^{-1}$ obtained with the maximum $\mathrm{DE}$ proportion represents a low value of this element in the substrate, with no risk of toxicity to plants.

The Se contents obtained in the present research were very low, due to the also low contents in the SS and DE (Table 1); there was a reduction of $0.08 \mathrm{mg} \mathrm{kg}^{-1}$ as the DE was added. Dores-Silva et al. (2011a) obtained much higher content in SS vermicompost, equal to $76.06 \mathrm{mg} \mathrm{kg}^{-1}$. Furthermore, for the registration of the product according to the IN 27/2006 (BRASIL, 2006a), the limit is $80 \mathrm{mg} \mathrm{kg}^{-1}$, whereas for the CONAMA resolution 375 (BRASIL, 2006b) it is $100 \mathrm{mg} \mathrm{kg}^{-1}$, which are much higher than the observed mean value of $0.2 \mathrm{mg} \mathrm{kg}^{-1}$.

The As contents were not influenced by the different proportions of DE added to the PC. This fact is satisfactory because, at all tested quantities of $\mathrm{DE}$, it was not possible to reach the maximum value of $41 \mathrm{mg} \mathrm{kg}^{-1}$ established by the CONAMA resolution 375 (BRASIL, 2006b). Also for the registration of the product according to the IN 27/2006 (BRASIL, 2006a), the limit is $20 \mathrm{mg} \mathrm{kg}^{-1}$, thus above the obtained mean value of $0.22 \mathrm{mg} \mathrm{kg}^{-1}$.
According to the CONAMA resolution 375 (BRASIL, 2006b), the critical contents are 2,800 $\mathrm{mg} \mathrm{kg}^{-1}$ for $\mathrm{Zn}$ and 1,500 $\mathrm{mg} \mathrm{kg}^{-1}$ for $\mathrm{Cu}$. Therefore, with the process of vermicomposting, the elements are within the limits allowed for the agricultural use of the vermicompost. Panday et al. (2014) report that earthworms can absorb toxic elements in their tissues during the process of vermicomposting, which can partially explain the reductions of the metals in the generated substrate.

There was increment of $\mathrm{Na}$ with the addition of DE to the vermicompost (Table 2). Although $\mathrm{Na}$ is not an element highly concentrated in the SS and in the DE (Table 1), the DE shows a higher content, which led to the increase of $690.97 \mathrm{mg} \mathrm{kg}^{-1}$ in the content of the vermicompost, with the increase in DE proportion. In addition, there was an increment of the content in relation to the original substrates, due to the reduction in the vermicompost biomass by the decomposition. A similar result was reported in the study of Orrico Júnior et al. (2012), in which the $\mathrm{Na}$ content increased from 6.30 to $8.70 \mathrm{~g} \mathrm{~kg}^{-1}$ during the vermicomposting of beef cattle wastes.

Cation exchange capacity (CEC) decreased from 547.1 to $382.7 \mathrm{mmol} \mathrm{kg}^{-1}$ as DE was added (Table 2). This fact can be justified because the $\mathrm{DE}$ is an inert material, reducing the CEC when added to the PC (Table 1). Pigozzo et al. (2008) reported increase of CEC due to the SS. Therefore, if there is a reduction in the amount of organic matter in the vermicompost mixed with DE, the CEC of the generated substrate will also be reduced; however, its value is still considered as good and approximately three times higher than that found by Cardoso et al. (2011) in the application of $120 \mathrm{t} \mathrm{ha}^{-1}$ of organic compost. Corrêa et al. (2006) also corroborate the obtained results, since these authors found low CEC for the production of coffee seedlings in soil with addition of DE. On the other hand, the $\mathrm{CEC} / \mathrm{C}$ ratio, which evaluates if organic matter humification was efficient, demonstrates that there were no differences between the different proportions of DE (Table 2).

The $\mathrm{C} / \mathrm{N}$ ratio of the vermicompost was $28 \%$ higher than that recommended by the IN 25/2009 (BRASIL, 2009), which establishes maximum value of 14 , and the produced substrate, despite exhibiting constant behavior regardless of the added amount of DE, showed mean value of 17.93 (Table 2). The C/N ratio indicates the maturation of the vermicompost; the lower the ratio, the more advanced the maturation process. Such result was very similar to that obtained by Dores-Silva et al. (2011a), who found C/N ratio of 16.69 in SS vermicompost at 90 days of vermicomposting. However, in order to meet the IN 25/2009 (BRASIL, 2009), the product can be registered for commercialization as organic compost in the $\mathrm{D}$ class, whose maximum allowed $\mathrm{C} / \mathrm{N}$ ratio is 20 . For this specification, all other evaluated attributes also met the criteria.

The $\mathrm{pH}$ of the vermicompost increased from 5.99 to 6.23 with the increment in DE, which can be attributed to the increase of about 5.3 times in the $\mathrm{Na}$ content with the utilization of the highest DE proportion in the substrate (Table 2). These values were higher than that obtained by Dores-Silva et al. (2011a), with SS vermicomposted for 90 days, whose $\mathrm{pH}$ was equal to 5 . However, the production of vermicompost with $30.12 \%$ of DE promotes a $\mathrm{pH}$ value that meets the IN 25/2009 (BRASIL, 2009), which determines $\mathrm{pH}$ of at least 6. 


\section{Conclusions}

1. Diatomaceous earth can be vermicomposted, even soaked in biofuel oil, in quantities of up to $30.12 \%(\mathrm{v} / \mathrm{v})$ of the mixture with pre-compost of sewage sludge and plant residues, without visible physical damages to the Eisenia foetida earthworms.

2. The vermicompost of sewage sludge, plant residues and diatomaceous earth at the proportion of $30.12 \%(\mathrm{v} / \mathrm{v})$, despite reducing the contents of the nutrients, meets all criteria established for agricultural use, registration and commercialization of the product as organic compost, as established in the Normative Instructions 25/2009 and 27/2006 of the Ministry of Agriculture.

\section{ACKnowledgments}

To the Federal University of Minas Gerais (UFMG), Minas Gerais Research Support Foundation (FAPEMIG) and Coordination for the Improvement of Higher Education Personnel (CAPES), for the financial support to the project and for granting the scholarship; to the Minas Gerais Sanitation Company (COPASA) and Brazilian Petroleum Corporation (PETROBRAS), for donating the sewage sludge and diatomaceous earth.

\section{Literature Cited}

Alcarde, J. C. Manual de análise de fertilizantes. Piracicaba: FEALQ, 2009. 259p.

Barbosa, G. M. de C.; Tavares Filho, J.; Brito, O. R.; Fonseca, I. C. de B. Equilíbrio de bases no solo e produção de matéria seca de milho (Zea mays L.) em solos tratados com lodo de esgoto, carbonato de cálcio e cal virgem. Acta Scientiarum. Agronomy, v.29, p.709-714, 2007.

Brasil. Ministério da Agricultura, Pecuária e Abastecimento. Secretaria de Defesa Agropecuária. Instrução Normativa n.27, de 09 de junho de 2006. Disponível em: <https://www.legisweb.com.br/ legislacao/?id=76854>. 2006a. Acessado em: 24 Mai. 2015.

Brasil. Ministério do Meio Ambiente. Conselho Nacional de Meio Ambiente. Resolução n.375, de 29 de agosto de 2006. Disponível em: <http://www.fundagresorg.br/biossolido/images/downloads/ res_conama37506>. 2006b. Acessado em: 20 Abr. 2014.

Brasil. Ministério da Agricultura, Pecuária e Abastecimento. Secretaria de Defesa Agropecuária. Instrução normativa n.25, de 23 de julho de 2009. Disponível em: <http://www.dpv24.iciag.ufu.br/new/ dpv24/Apostilas/IN\%20MAPA\%2025\%202009.pdf>. Acessado em: 24 Nov. 2016.

Caldeira, M. V.; Delarmelina, W. M.; Peroni, L.; Gonçalves, E. de O.; Silva, A. G. da. Lodo de esgoto e vermiculita na produção de mudas de eucalipto. Pesquisa Agropecuária Tropical, v.43, p.155163, 2013. https://doi.org/10.1590/S1983-40632013000200002

Cardoso, A. I. I.; Ferreira, K. P.; Vieira Júnior, R. M.; Alcarde, C. Alterações em propriedades do solo adubado com composto orgânico e efeito na qualidade de sementes de alface. Horticultura Brasileira, v.29, p.594-599, 2011.https://doi.org/10.1590/S0102-05362011000400025

Corrêa, J. C.; Bül, L. T.; Mauad, M.; Tecchio, M. A.; Crusciol, C. A. C. Caracterização química em substratos de resíduos industriais e urbanos para a obtenção de mudas de café. Científica, v.34, p.238-248, 2006.
Corrêa, R. S.; Fonseca, Y. M. F.; Corrêa, A. S. Produção de biossólido agrícola por meio da compostagem e vermicompostagem de lodo de esgoto. Revista Brasileira de Engenharia Agrícola e Ambiental, v.11, p.420-426, 2007.https://doi.org/10.1590/S1415-43662007000400012

Dores-Silva, P. R.; Landgraf, M. D.; Rezende, M. O. O. Acompanhamento químico da vermicompostagem de lodo doméstico. Química Nova, v.34, p.956-961, 2011a. https://doi.org/10.1590/S010040422011000600008

Dores-Silva, P. R.; Landgraf, M. D.; Rezende, M. O. O. Avaliação do potencial agronômico de vermicomposto produzido a partir de lodo de esgoto doméstico. Revista Brasileira de Ciências Agrárias, v.6, p.565-571, 2011b. https://doi.org/10.5039/agraria.v6i4a909

EPA - Environmental Protection Agency. Microwave assisted acid digestion of sediments, sludges, soils, and oils. Method 3051, 1994. 14p. Disponível em: <http://cem.com/media/contenttype/media/ literature/516_MetNote_DiscSPD_EPA_3051.pdf $>$. Acessado em: 14 Set. 2016.

Goulart, M. R.; Silveira, C. B. da; Campos, M. L.; Almeida, J. A. de; Manfredi-Coimbra, S.; Oliveira, A. F. de. Metodologias para reutilização do resíduo de terra de diatomácea, proveniente da filtração e clarificação de cerveja. Química Nova, v.34, p.625-629, 2011. https://doi.org/10.1590/S0100-40422011000400014

Hashemimajd, K.; Jamaati-e-Somarin, S. Contribution of organic bulking materials on chemical quality of sewage sludge vermicompost. Ciência e Agrotecnologia, v.35, p.1077-1084, 2011. https://doi.org/10.1590/S1413-70542011000600006

Lopes, J. L. W.; Guerrini, I. A.; Saad, J. C. C.; Silva, M. R. da. Atributos químicos e físicos de dois substratos para produção de mudas de eucalipto. Revista Cerne, v.14, p.358-367, 2008.

Nascimento, A. L.; Sampaio, R. A.; Cruz, S. F. da; Zuba Junio, G. R.; Barbosa, C. F.; Fernandes, L. A. Metais pesados em girassol adubado com lodo de esgoto submetido a diferentes processos de estabilização. Revista Brasileira de Engenharia Agrícola e Ambiental, v.18, p.694699, 2014. https://doi.org/10.1590/S1415-43662014000700004

Nascimento, A. L.; Sampaio, R. A.; Fernandes, L. A.; Zuba Junio, G. R.; Carneiro, J. P.; Rodrigues, M. N.; Albuguerque, H. C. de. Yield and nutrition of sunflower fertilized with sewage sludge stabilized by different processes. Revista Ceres, v.60, p.683-689, 2013. https:// doi.org/10.1590/S0034-737X2013000500012

Orrico Júnior, M. A. P.; Orrico, A. C. A.; Lucas Júnior, J. de; Sampaio, A. A. M.; Fernandes, A. R. M.; Oliveira, E. A. de. Compostagem dos dejetos da bovinocultura de corte: Influência do período, do genótipo e da dieta. Revista Brasileira de Zootecnia, v.41, p.13011307, 2012. https://doi.org/10.1590/S1516-35982012000500030

Panday, R.; Basnet, B. B.; Bhatt, P. S.; Tamrakar, A. S. Bioconcentration of heavy metals in vermicomposting earthworms (Eisenia fetida, Perionyx excavatus and Lampito mauritii) in Nepal. Journal of Microbiology, Biotechnology and Food Sciences, v.3, p.416-418, 2014.

Paredes Filho, M. V. Compostagem de lodo de esgoto para uso agrícola. Revista Agrogeoambiental, v.3, p.73-80, 2011. https:// doi.org/10.18406/2316-1817v3n32011364

Pigozzo, A. T. J.; Lenzi, E.; Lucas Júnior, J. de; Scapim, C. A.; Vidigal Filho, P. S.; Costa A. C. S. da. Reação do solo e disponibilidade de micronutrientes, em solo de textura média, tratado com lodo de esgoto e cultivado com milho. Acta Scientiarum Agronomy, v.30, p.569-579, 2008.

Tedesco, M. J.; Gianello, C.; Bissani, C. A.; Bohnen, H.; Volkweiss, S. J. Análise de solo, plantas e outros materiais. 2.ed. Porto Alegre: Departamento de Solos - Universidade Federal do Rio Grande do Sul, 1995. 174p. 